\author{
Elwira Żmudzka \\ University of Warsaw \\ Faculty of Geography and Regional Studies \\ Department of Climatology \\ e-mail: elwiraz@uw.edu.pl
}

\title{
CONTEMPORARY CLIMATE CHANGES IN THE HIGH MOUNTAIN PART OF THE TATRAS
}

\begin{abstract}
The purpose of this study was to determine the contemporary changes of precipitation and nival conditions in the high-mountain area of Tatras. Main features of thermal climate changes are the background of this investigation. The study makes use of the daily data from the weather station on Kasprowy Wierch Mt. from the years 1966-2006. Various climate characteristics were considered. The increase of the air temperature is not accompanied by significant changes in precipitation conditions. The signs of the more continentality climate features are also visible. The warming and a slight decrease in precipitation and the evolution of circulation conditions significantly influence the length of the period with the snow cover and not significantly its depth.
\end{abstract}

Key words: air temperature, precipitation, snow cover, trend, Tatra Mountains

\section{INTRODUCTION}

The main purpose of this study is the determination of the scale, direction and seasonal distribution of contemporary changes of some climate elements in the high-mountain part of Tatra Mountains. This is the attempt to answer the question if the increase of air temperature in Tatras is accompanied with significant changes of pluvial and nival conditions. Heat store, and the amount, frequency and intensity of precipitation are main factors determining the ecosystem functionality. They also assign the conditions and possibilities of different management forms. The snow cover may be considered as the complex climate indicator, its occurrence and features are the resultants of the whole complex of atmospheric factors (atmospheric circulation, and such climate elements as air temperature, precipitation, radiation, insolation, wind velocity and others) and these ones connected to the earth surface, inter alia relief and vegetation. Long-term differentiation of nival conditions are mostly caused by the first mentioned factors. 


\section{MATERIALS AND METHODS}

Homogenous daily data series of the 1966-2006 time period from highmountain IMGW meteorological station on Kasprowy Wierch (1991 m a.s.l.) were used to determine the contemporary climate changes in the highmountain area of the Tatra Mountains. Mentioned station is situated on the peak mountain in a depression in the main Tatras ridge.

The background of the investigation are the thermal condition changes on Kasprowy Wierch Mt. (Żmudzka 2009b, 2010a, b). Additionally long-term changes of pluvial characteristics were determined: seasonal and annual precipitation, number of days with precipitation and mean precipitation intensity (abundance), defined as the ratio of the precipitation sum and days with precipitation. Particular attention was focused on the changes of the number of the days with very high precipitation (daily amount $\geq 30.0 \mathrm{~mm}$, $\geq 50.0 \mathrm{~mm}$ and $\geq 100.0 \mathrm{~mm}$ ) and their participations in the total precipitation sum. Snow cover was characterized by computing the number of days with snow cover, its mean and maximum depth and cumulative sums of snow cover depth in the following periods: December-February (climatic winter), October-April and the whole year (August-July). Also the dates of the snow cover appearance and disappearance are included. In this case the earliest and the latest days with permanent snow cover for the long-term period were given (the period of discontinued snow cover may be three days within thirty). Mean dates of the beginning and the end of snow cover occurrence were calculated as well.

General direction and tempo of changes of climatic conditions were determined on the base of linear trends. There were also calculations resulting in what percent the variability of particular climate elements may be explained by these trends.

\section{LONG-TERM CHANGES OF THERMAL CONDITIONS}

The characteristic feature of the changes of thermal conditions in the high-mountain area of Tatras in the period 1966-2006 was the increase of mean annual air temperature about $0.02^{\circ} \mathrm{C}$ per year (Table 1 ). The similar rate of growth of the air temperature was stated also in other mountain areas in the central part of Europe, e.g. in the Karkonosze, in the Alps and in the Carpathian Mountains (see, e.g., Głowicki 1998, Migała 2005, Weber et al. 1997).

Another visible features of the long-term annual temperature course are a dozen of years fluctuations within the amplitude of $2-4^{\circ} \mathrm{C}$ (Żmudzka $2009 \mathrm{~b}$, 2010a) (Fig. 1).

The warming is marked in all seasons but the highest and statistically significant increase of the temperature occurred during summer $\left(0.04^{\circ} \mathrm{C}\right.$ per year, Table 1). The increase of the temperature during winter season looked the same like the mean annual temperature increase. However the trends 

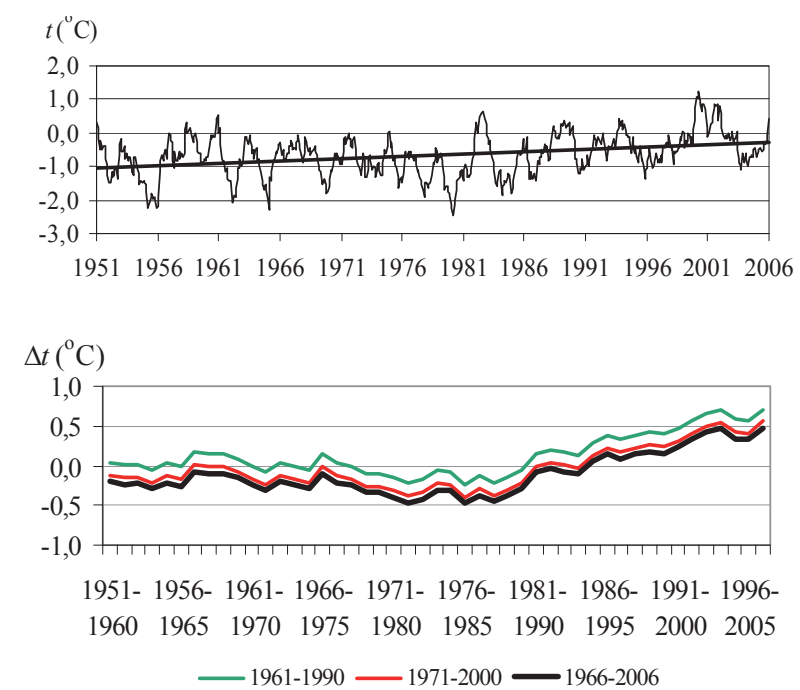

Fig. 1. Moving averages 12-monthly values of the air temperature in the years 1951-2006 and their linear trend (higher graph) and deviations $(\Delta t)$ of annual average air temperature from average in periods 1961-1990, 1971-2000 i 1966-2006 (moving 10-year average, lower graph) on Kasprowy Wierch Mt.

in both cases were not statistically significant. The highest increase of mean air temperature in the warmest months than during the coldest cause the annual air temperature amplitude raised of $0.04^{\circ} \mathrm{C}$ per year which indicates the increase of the importance of thermal continentality features.

Positive trends of changes of annual minimal and maximal temperatures (statistically important in the summer time) caused the significant increase of the air temperature. The increase of maximal temperature was slightly higher than the minimal one what brought the raise of the daily air temperature amplitude, visible during the whole year and particularly in the summer $\left(0.02^{\circ} \mathrm{C}\right.$ per year). Monthly, slight decrease of extreme temperatures was only marked at the turn of winter and spring (February and March) (Żmudzka 2010a).

The decrease of the number of ice days $\left(t_{\max }<0^{\circ} \mathrm{C}\right)$ in the high-mountain part of the Tatras is the very important feature characterizing the changes of thermal conditions at the turn of XX and XXI centuries. Such days are the most numerous within a year on Kasprowy Wierch Mt. (40\% in a year and $86 \%$ in a winter). Another important features are the increase of the number of frost days $\left(t_{\min }<0^{\circ} \mathrm{C}, t_{\max }>0^{\circ} \mathrm{C}\right)$ and very ice days $\left(t_{\min }<-10^{\circ} \mathrm{C}\right)$ (Żmudzka 2010a).

Characteristic features of the investigated period were not only milder and shorter winter seasons but also the significant increase of the heat store in the vegetative season (positive trend of the sum of daily temperatures higher than $5^{\circ} \mathrm{C}$ was $3.4^{\circ} \mathrm{C}$ per year) (Żmudzka 2010a). 
Table 1. Directional coefficients $(a)$ of the trend in changes of the chosen thermal characteristics on Kasprowy Wierch Mt. in the years 1966-2006. Coefficients significant at the level of 0.05 are marked in bold (Żmudzka 2009b, 2010a)

\begin{tabular}{|c|c|c|c|c|c|c|c|}
\hline \multicolumn{2}{|c|}{ Characteristic } & $a$ & DJF & MAM & JJA & SON & Year \\
\hline \multirow{4}{*}{ 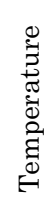 } & Average & \multirow{4}{*}[{}^{\circ}\mathrm{C}\cdot\text{year}^{-1}]{} & 0.02 & 0.01 & 0.04 & 0.01 & 0.02 \\
\hline & Minimum & & 0.01 & 0.00 & 0.03 & 0.01 & 0.01 \\
\hline & Maximum & & 0.03 & 0.01 & 0.05 & 0.01 & 0.03 \\
\hline & Daily amplitude & & 0.02 & 0.01 & 0.02 & 0.00 & 0.01 \\
\hline \multirow{3}{*}{$\stackrel{\infty}{\overparen{\pi}}$} & frost & \multirow{3}{*}{ [days ' year ${ }^{-1}$ ] } & 0.22 & 0.13 & -0.11 & 0.04 & 0.30 \\
\hline & ice & & -0.24 & -0.07 & 0.00 & -0.03 & -0.41 \\
\hline & very ice & & 0.04 & 0.04 & - & 0.01 & 0.10 \\
\hline
\end{tabular}

\section{LONG-TERM CHANGES OF PLUVIAL CONDITIONS}

The increase of the air temperature in the high-mountain part of Tatras in the period 1966-2006 were not accompanied by significant changes of the amount and character of precipitation (extreme and mean). Linear trends are not statistically significant (explain only a few percent of the variability of particular pluvial characteristics) and not stable in time. A dozen of years fluctuations of the long-term precipitation course are very characteristic.

The mean annual precipitation in the investigated years decreased with the tempo of $2.6 \mathrm{~mm}$ per year (Table 2) and the mean value for this period was $1797.7 \mathrm{~mm}$ on Kasprowy Wierch Mt. The extreme years were 2001 where annual precipitation achieved $2600.3 \mathrm{~mm}$ and 1993 with the value of 1292.3 $\mathrm{mm}$ (Fig. 2). These two years are also marked as these with the smallest $(1993-95.5 \mathrm{~mm})$ and the highest $(2001-612.9 \mathrm{~mm})$ annual amplitude of precipitations. The second case (2001) was connected with the extremely high precipitation during summer months effected by extremely big number of days with very high precipitation (Żmudzka 2010c).

Seasonal tendencies of pluvial characteristics were differentiated during a year. The precipitation decrease in 1966-2006 period occurred mainly in the winter season $-2.0 \mathrm{~mm}$ per year. Precipitation increased in the autumn season and the number of days with precipitation decreased what caused

Table 2. Directional coefficients $(a)$ of the trend in changes of the selected characteristics precipitation on Kasprowy Wierch Mt. (1966-2006)

\begin{tabular}{|l|l|r|r|r|r|r|}
\hline \multicolumn{1}{|c|}{ Characteristic } & \multicolumn{1}{|c|}{$\boldsymbol{a}$} & DJF & MAM & JJA & SON & Year \\
\hline Precipitation totals & {$\left[\mathrm{mm} \cdot\right.$ year $\left.^{-1}\right]$} & -2.04 & -0.27 & -1.25 & 1.33 & -2.64 \\
\hline Number of days with precipitation & {$\left[{\left.\text { number of days } \cdot \text { year }^{-1}\right]}^{-1}-0.03\right.$} & 0.02 & -0.05 & -0.01 & -0.09 \\
\hline Average precipitation abundance & {$\left[\mathrm{mm} \cdot\right.$ day $^{-1} \cdot$ year $\left.^{-1}\right]$} & -0.03 & -0.01 & -0.02 & 0.02 & -0.01 \\
\hline
\end{tabular}



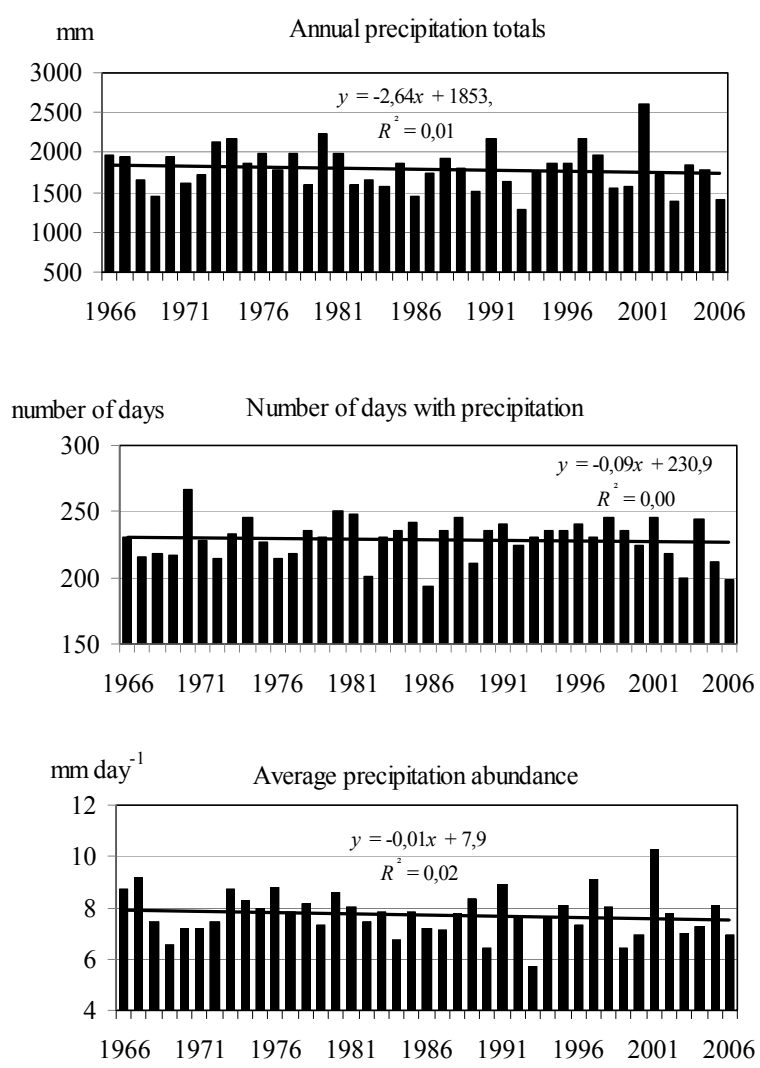

Fig. 2. Long-term variation of the annual precipitation totals, number of days with precipitation and average precipitation abundance on Kasprowy Wierch Mt. (1966-2006). The line represents linear trend (Żmudzka 2010c, changed)

the increase of precipitation intensity during this period. The mean precipitation abundance decreased during the rest of the year (Żmudzka 2010c).

The increasing precipitation tendency during the autumn and decreasing in the spring cause the decrease of the ratio of spring and autumn precipitations about 0.01 per year (the precipitation in the spring was in average 1.3 times higher than during autumn). On the other hand the changes tendency of the ratio of summer and winter precipitations was positive $(0.01$ per year and 2.0 in the long-time average).

The slight decrease ( 0.05 day per year) of the mean annual number of days with precipitation higher or equal $30 \mathrm{~mm}$ was marked in the investigated period. Participation of these days in the total precipitation sum also decreased $(-0.10 \%$ per year). The trend of number changes of days with precipitation of at least $50 \mathrm{~mm}$ was not observed. The mean annual number of days with very high precipitation ( $\geq 30 \mathrm{~mm}$ ) was 10 on Kasprowy Wierch Mt. Three days with precipitation higher or equal $50 \mathrm{~mm}$ occurred in average but 
days with very high precipitation may be observed during the whole year however are concentrated in the summer season (respectively 5 and 2 days). The highest number of days with precipitation $\geq 30 \mathrm{~mm}$ and $\geq 50 \mathrm{~mm}$ as well occurred in the year of the highest annual precipitation (2001) and were respectively 20 and 12 (14 and 11 during summer season) (Żmudzka 2010c).

Daily precipitation on Kasprowy Wierch Mt., higher or equal $100 \mathrm{~mm}$ were observed eight times but six of them occurred in the warmest period i.e. after 1980 . However the highest daily precipitation $(232.0 \mathrm{~mm})$ from the June $30^{\text {th }}$ of 1973 was not exceeded.

\section{LONG-TERM CHANGES OF NIVAL CONDITIONS}

The snow cover on Kasprowy Wierch Mt. may occur almost in the whole year. It did not appear during the investigation period only between the July $25^{\text {th }}$ and August $2^{\text {nd }}$ (Table 3). The average occurrence of the snow cover started in September $9^{\text {th }}$ and ended in June $25^{\text {th }}$. The period with permanent snow cover was slightly shorter and ranged the period from November $5^{\text {th }}$ till May $19^{\text {th }}$. It is connected with the weather variability and often appearances of long- and short-term thaws in temporary year seasons. The highest variability of the number of days with snow cover occurs in September, October and May and of the sum of depth of snow cover in October (the quotient of the sum maximal and minimal in the investigated period was 1729). The variability of the sum of snow cover depth was 3.4-4.5 during the climatic winter, in the period from October to April and in the whole year. Variability of sum annual snow cover depth is determined in $71 \%$ by this sum depth during winter season and in 97\% from the months October-April. It is worth of mentioning that in 31 of 41 years from the investigated period the maximal depth of snow cover occurred beyond the winter season. This situation was permanently observed from 1992 (fig. 3).

Table 3. The dates of the beginning and end of snow cover on Kasprowy Wierch Mt. (1965/662005/06). Coefficients significant at the level of 0.05 are marked in bold

\begin{tabular}{|c|c|c|c|c|c|}
\hline Average & \multicolumn{2}{|c|}{ The earliest } & \multicolumn{2}{|c|}{ The latest } & $\begin{array}{c}\text { Tendency } \\
{\left[\text { days } \cdot \text { year }^{-1}\right]}\end{array}$ \\
\hline \multicolumn{6}{|c|}{ The first day with the snow cover } \\
\hline 9 IX & 2 VIII & 1989 & $19 \mathrm{X}$ & 1967 & -0.30 \\
\hline \multicolumn{6}{|c|}{ The first day with the permanent snow cover } \\
\hline $5 \mathrm{XI}$ & $23 \mathrm{IX}$ & 1972 & $10 \mathrm{XII}$ & 2000 & 0.38 \\
\hline \multicolumn{6}{|c|}{ The last day with the snow cover } \\
\hline $25 \mathrm{VI}$ & $21 \mathrm{~V}$ & 1979 & $25 \mathrm{VII}$ & 1986 & -0.46 \\
\hline \multicolumn{6}{|c|}{ The last day with the permanent snow cover } \\
\hline $19 \mathrm{~V}$ & $26 \mathrm{IV}$ & 1986 & $11 \mathrm{VI}$ & 1991 & 0.14 \\
\hline
\end{tabular}



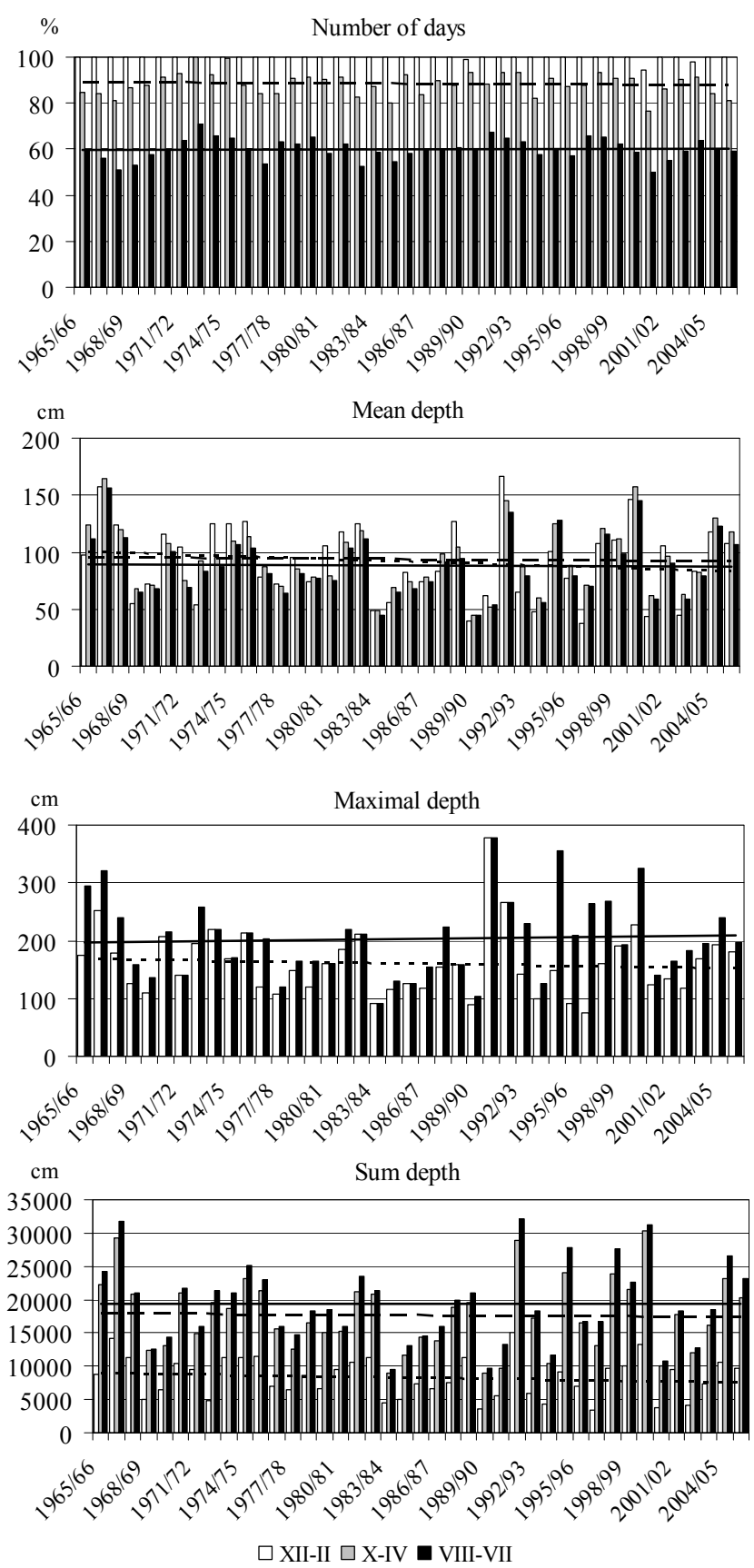

Fig. 3. Long-term variation of the characteristics of snow cover in winter, in the period from October to April and in the whole year on Kasprowy Wierch Mt. (1965/66-2005/06). The line represents linear trend 
The permanent snow cover was formed in the autumn but in the period 1965/66-2005/06 it started later and later (0.4 days per year). However the first day with snow cover appeared still earlier and the period with snow cover also ended earlier (Table 3).

The tendencies of changes of snow cover characteristics in the investigation period was negative during winter season but only the trend of changes of the number of days with snow cover was statistically significant (-0.02 days per year, tab. 4). Winter on Kasprowy Wierch Mt. is a quite stable season for the lasting time of snow cover existence. The snow cover appears generally in all days (long-term average of the number of days with snow cover states the $99.8 \%$ of all winter days). However, in the warmest period (after 1987), there were three seasons with the smaller number of days with the snow cover. These were winters of 1989/90, 2000/01 (94\% of all days) and 2003/04. Years 2000, 2002 and 2003 were the warmest from 1951 and the mean annual temperature on Kasprowy Wierch Mt. was then above $0^{\circ} \mathrm{C}$. Still milder and so called non-nuclear winters generated less stable snow cover and even caused it did not occur. Especially warm were winter seasons of $1989 / 90$ and 2000/01. The season 2003/04, despite the mean winter air temperature was not the highest in the considered period, was characterised by the occurrence of a few days permanent period with the daily air temperature above $0^{\circ} \mathrm{C}$ (in the $4^{\text {th }}$ of December 2003 it was even $7.4^{\circ} \mathrm{C}$ ). This thaw caused the disappearance of the snow cover which was not permanent and especially of small depth also during November.

Table 4. Directional coefficients $(a)$ of the trend in changes of the selected characteristics snow cover on Kasprowy Wierch Mt. (1966-2006). Coefficients significant at the level of 0.05 are marked in bold

\begin{tabular}{|l|c|c|c|c|}
\hline \multicolumn{1}{|c|}{ Characteristic } & $\boldsymbol{a}$ & DJF & O-A* & Year \\
\hline Number of days & {$\left[\% \cdot\right.$ year $\left.^{-1}\right]$} & $\mathbf{- 0 . 0 2}$ & -0.04 & 0.02 \\
\hline Mean depth & \multirow{3}{*}[\mathrm{cm}^{*}\text{year}^{-1}]{} & -0.42 & -0.08 & -0.06 \\
\cline { 4 - 6 } & & -0.40 & \multicolumn{2}{|c|}{0.34} \\
\cline { 1 - 4 } Maximal depth & & -39.30 & -17.78 & -0.14 \\
\hline Sum depth & &
\end{tabular}

* - period between October-April

Snow cover characteristics from October till April and during the whole year generally did not mark the trend of changes in the investigation period. The poor negative trend was only observed in case of the number of days with snow cover in months from October till April. Slight negative trends of changes of mean, maximal and sum depth of the snow cover were resulted from the increase of the air temperature (still shorter winter seasons, occurrence of non-nuclear winters, the air temperature increase in the spring and summer seasons), the number of days with precipitation and its amount.

It is distinctive that in average, the trends of changes in the number of days with snow cover and its maximal depth were positive which may indi- 
cate more often occurrence of snow cover behind the main season of its appearance. Carried out analyses displayed slight increase of mentioned snow cover characteristics in June and September.

The investigated period may be divided into three ones when the characteristics of snow cover depth differentiated in the range of changes. 70's and 80's had noticeable small changes in the snow cover depth comparing to the previous years and at the turn of XX and XXI centuries. This reflects the transformations of circulation conditions in the investigated period. West directed advection conditions were frequently observed over the centre part of Europe in 70's and 80's. The beginning of the second half of the XX century and the turn of XX and XXI centuries were characterised by higher contribution of the meridional atmospheric circulation.

\section{DISCUSSION AND CONCLUSION}

Determining the climate changes in the mountain areas is very important because such ecosystems are very sensitive and susceptible to climate transformations. Besides, data series coming from high-mountain regions are especially valuable source materials in the investigations dealing with the climate evolution. They are just not influenced by such anthropogenic activities like urbanization and all changes in land use.

The carried out analysis allow to express some conclusions:

- the characteristic feature of contemporary climate changes in the highmountain area of Tatras is warming, comparable to the air temperature increase in the lowland parts of Poland and in a wide range of Central Europe (Żmudzka, 2009a, 2010b), but slightly poorer and statistically not significant;

- the last years of $20^{\text {th }}$ century and the first of $21^{\text {st }}$ brought the rise of the tempo of the air temperature increase and the change in the seasonal distribution of this process, of course in comparison to the second half of the $20^{\text {th }}$ century when the air temperature positive trends during winter-spring season existed but the significant increase of the summer season temperature occurred just at the turn of the centuries. Elongating the investigation period to the very beginning years of $21^{\text {st }}$ century indicate the increase of the level of continentality conditions in thermal and pluvial phenomena which is inter alia visible by the increase of their annual amplitudes;

- the increase of the air temperature in the high-mountain area of Tatras is not accompanied by significant changes in the amount and character of precipitation, mean and extreme as well. The depth of snow cover is also not significantly related to the mentioned increase. Only the number of days with the snow cover decreased significantly. Besides forming of the permanent snow cover occurred still later in the autumn season and still earlier the days with this cover ended in the spring; 
- linear trends of changes in climatic elements explain their variability only in a few percents. The characteristic feature of these elements in case of their courses are a dozen years of fluctuations;

- special and temporal discontinuities and great variability of precipitation and the snow cover, especially expressed in mountain areas (see, e.g.,. Chomicz 1959, Cebulak 1991), cause the investigated results should be interpreted very carefully. The answer for the question if the increase of the air temperature in the high-mountain areas of Tatras is accompanied with significant changes in the volume and character of precipitation and in the depth of the snow cover and its time occurrence, could be more completed if the analysis was done with data from more meteorological stations.

\section{REFERENCES}

Cebulak E., 1991, Najwyższe zanotowane maksymalne opady dobowe w dorzeczu górnej Wisły $\mathrm{i}$ ich geneza [The highest observed maximal daily precipitation in the higher Vistula basin and its genesis], Acta Universitatis Wratislaviensis, Prace Instytutu Geograficznego, 1213, 167-171.

Chomicz K., 1959, Opady w Zakopanem [Precipitation in Zakopane], Wiad. St. Hydr. i Met., 6, $5,207-215$.

Głowicki B., 1998, Wieloletnia seria temperatury powietrza na Śnieżce [Long-term series of the air temperature on Śnieżka]. [in:] Geoekologiczne problemy Karkonoszy. Materiaty konferencyjne. Acarus, Poznań, 117-124.

Migała K., 2005, Piętra klimatyczne w górach Europy a problem zmian globalnych [Climatic belts in the European mountains and the issue of global changes]. Acta Universitatis Wratislaviensis, 2718, Studia Geograficzne 78, 149.

Weber R. O., Talkner P., Auer I., Böhm R., Gajić-Čapka M., Zaninović K., Brázdil R., Faško P., 1997, 20th-century changes of temperature in the mountain regions of Central Europe, Climatic Change, 36, 327-344.

Żmudzka, E., 2009a, Współczesne zmiany klimatu Polski [Contemporary changes of the climate of Poland]. Acta Agrophysica, 167, 555-568.

Żmudzka E., 2009b, Changes of thermal conditions in the Polish Tatra Mountains, Landform Analysis, 10, 140-146.

Żmudzka E., 2010a, Sygnał globalnego ocieplenia w Tatrach [Indication of global warming in Tatra Mountains], Tatry, TPN, 31, 1, 44-47.

Żmudzka E., 2010b, Changes in thermal conditions in the high mountain areas and contemporary warming in the central Europe. Miscellanea Geographica, 14, 59-70.

Żmudzka E., 2010c, Współczesne zmiany wielkości i charakteru opadów w Tatrach [Contemporary changes of the precipitation volume and character in Tatra Mountains], [in: Nauka a zarzqdzanie obszarem Tatr $i$ ich otoczeniem, t. 1, Zakopane, TPN, PTPNoZ Oddział Kraków, 157-164. 